\title{
CONDITIONING FACTORS OF “TERRAS CAÍDAS” IN LOWER SOLIMÕES RIVER - BRAZIL
}

\author{
Matheus Silveira de Queiroz \\ Universidade Federal do Amazonas - UFAM, Manaus, AM, Brazil \\ matheussilveiradequeiroz@gmail.com
}

Neliane de Sousa Alves

Universidade do Estado do Amazonas, Manaus, AM, Brazil nsalves@gmail.com

\begin{abstract}
The term "Terras Caídas" is used in Amazon to refer to processes of fluvial erosion and mass movements of large and moderate scale. It is a dynamic and complex multi-causal process that involves hydrodynamic, hydrostatic, climatic, neotectonic, lithological and anthropic factors, occurring together or separately. The objective of this work is to understand the conditioning factors of the phenomenon "Terras Caídas" in lower Solimões River - Brazil. For this purpose, the study area was monitored for 2 years (2017-2018) and data from satellite images; water discharge; flow velocity; suspended sediments; water level; precipitation; wind direction; seismic activity were obtained. The hydrodynamic factors and the rain influence the "Terras Caídas" more intensely during the river flood, the processes influenced by the wind direction occur throughout the hydrological year, but with greater intensity during storms. Hydrostatic pressure occurs more frequently in ebb causing landslides. The lithology influences the stability of the banks due to unconsolidated sediments, providing erosion and mass movements. It is observed that neotectonics was not important in increasing the intensity of the "Terras Caídas" in the study area in recent years. Human activity influences destroying riparian forests and the basal erosion caused by waves formed by boats in the region.
\end{abstract}

Keywords: “Terras Caídas”. Amazon. Solimões River. Erosion. Mass Movement.

\section{FATORES CONDICIONANTES DAS TERRAS CAÍDAS NO BAIXO RIO SOLIMÕES - BRASIL}

\begin{abstract}
RESUMO
O termo "Terras Caídas" é usado na Amazônia para designar processos de erosão fluvial e movimentos de massa de larga e moderada escala. É um processo dinâmico e complexo multicausal que envolve fatores hidrodinâmicos, hidrostáticos, climáticos, neotectônicos, litológicos e antrópicos, ocorrendo em conjunto ou separados. Este trabalho tem como objetivo compreender os fatores condicionantes do fenômeno das "Terras Caídas" no baixo rio Solimões - Brasil. Para isto a área de estudo foi monitorada durante dois anos (20172018) e foram obtidos dados de imagens de satélite; descarga de água; velocidade de fluxo; sedimentos em suspensão; nível da água; precipitação; direção do vento; atividade sísmica. Os fatores hidrodinâmicos e a chuva influenciam as "Terras Caídas" de forma mais intensa durante a cheia, os processos influenciados pela direção do vento ocorrem ao longo de todo o ano hidrológico, mas com maior intensidade durante as tempestades. A pressão hidrostática ocorre com maior frequência na vazante, causando deslizamentos. A litologia influencia na estabilidade das margens devido a sedimentos inconsolidados, proporcionando erosão e movimentos de massa. Observa-se que a neotectônica não foi importante no aumento da intensidade das Terras Caídas na área de estudo nos últimos anos. A atividade humana influencia desmatando matas ciliares e na erosão basal causada pelas ondas formadas por barcos na região.
\end{abstract}

Palavras-Chave: “Terras Caídas”. Amazônia. Rio Solimões. Erosão. Movimento de Massa.

\section{INTRODUCTION}

The term "Terras Caídas" has been widely used in the academic community by Tricart (1977); Sternberg (1998); Carvalho (2006; 2012); Igreja, Carvalho e Franzinelli (2010); Magalhães (2011); Freitas e Albuquerque (2012); Guerra e Guerra (2015); Marques (2017); Magalhães e Vieira (2018); Bandeira et al. (2018), among others. According to Carvalho (2006; 2012) this is the Amazonian term used by

$\begin{array}{lllll}\text { Caminhos de Geografia } \quad \text { Uberlândia-MG } & \text { v. 22, n. } 80 & \text { abr./2021 } & \text { p. 220-233 Página } 220\end{array}$


ribeirinhos (riverside people) to designate river erosion processes. However, "Terras Caídas" phenomenon is unique in the world, as it involves, in addition to fluvial erosion, moderate and large mass movements (BANDEIRA et al., 2018).

The process occurs with greater intensity in the Andean rivers (white water rivers) (CARVALHO, 2006; 2012). However, in rivers with clear and black waters the process also occurs on a smaller scale (IGREJA; CARVALHO; FRANZINELLI, 2010; BANDEIRA et al., 2018). Often the phenomenon takes on catastrophic proportions and can cause material damage and loss of life and adding large amounts of sediment and organic matter in river (CARVALHO, 2006; 2012; GUERRA and GUERRA, 2015).

The hydrodynamic abrasion processes resulting from the chemical and physical action of water on banks and bed are not sufficient to explain the phenomenon of "Terras Caídas" in Amazon (CARVALHO, 2006). According to Igreja, Carvalho, Franzinelli (2010) the process occurs due to several factors that can act together: Hydrodynamics; Hydrostatic Pressure; Climate Factors (rainfall and wind); Lithology and Neotectonics; Anthropic Interference.

The Amazon River has its sources located in the Andes, characterizing it as a white water river (SIOLI, 1965), and is the largest river in the world in water discharge with $209,000 \mathrm{~m}^{3} / \mathrm{s}$ (MOLINIER et al., 1996). In the Brazilian Amazon, after the border with Peru, the river is called Solimões, until the confluence with the Negro river in the region of the municipalities of Manaus and Iranduba, in Amazonas State. This work has the objective to understand the conditioning factors of phenomenon of the "Terras Caídas" in lower Solimões River - Brazil.

\section{STUDY AREA LOCATION}

Xiborena Island is located in the municipality of Iranduba - Amazonas, at the confluence of the Negro and Solimões rivers, the left bank of the Solimões river and the right bank of the Negro river. The area located on the Solimões River was defined as the study area. On the Xiborena Island there are four riverside rural communities, Santa Luzia, Bom Jesus do Paraná do Xiborena, Costa do Catalão (Solimões) and Lago do Catalão (Negro), the first three mentioned are within the research area (Figure 1).

Figure 1 - Study Area Location.

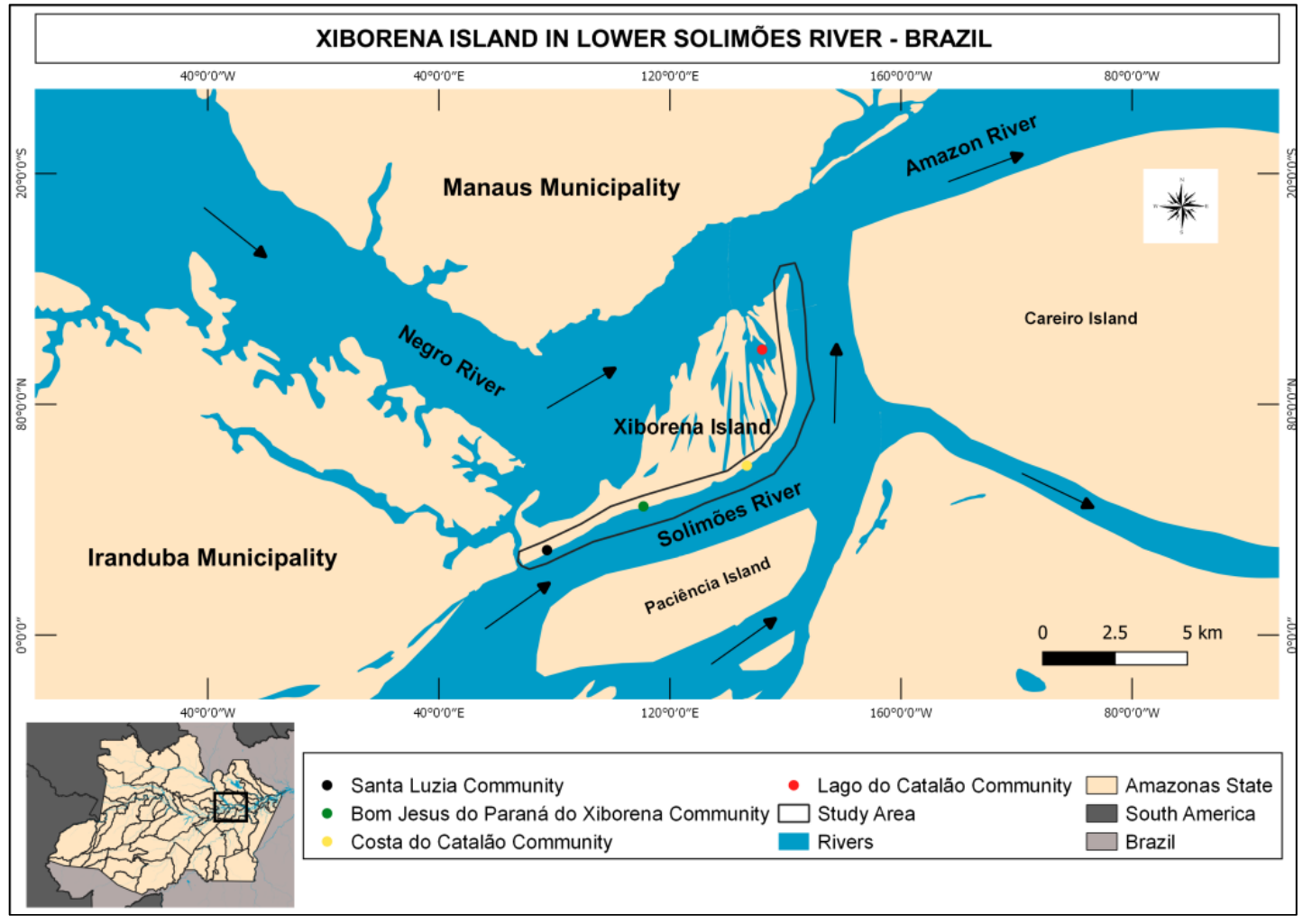

Arrows indicate flow direction. Org. - The Authors (2020). 


\section{METHODOLOGY}

The processes involving the erosion of the banks in mega rivers are complex and dynamic, therefore the study area was monitored for two years (2017-2018) during the flood and ebb periods of the Solimões River to identify the main conditioning factors of "Terras Caídas", hydrodynamic, hydrostatic, lithological and neotectonic, climatic (rainfall and wind) and anthropic factors were observed according to Carvalho (2006; 2012); Igreja, Carvallho and Franzinelli (2010) and Bandeira et al. (2018).

To complement the field data, secondary data from stations and satellites, obtained from the United States Geological Survey - USGS (https://earthexplorer.usgs.gov/) National Water Agency - ANA (http://www.ana.gov.br/) (Brazilian database) ; Ore-Hybam Project (http://www.ore-hybam.org/); National Meteorological Institute - INMET (http://www.inmet.gov.br/portal/) (Brazilian database); Brazilian Seismographic Network - RSBR (http://www.rsbr.gov.br/request.html) (Brazilian database) (Table 1):

Table 1 - Secondary data.

\begin{tabular}{|c|c|c|c|}
\hline \multirow{2}{*}{ Variable } & Period & Data Sets & Sources \\
\hline \multirow{2}{*}{ Satellite Image } & July -1992 & \multirow{2}{*}{ Landsat 5 and 8} & USGS \\
\cline { 2 - 2 } & August -2001 & & \\
\cline { 2 - 2 } & July - 2010 & & HYember - 2019 \\
\cline { 2 - 2 } Water Discharge & $1973-2018$ & Manacapuru (14100000) & HYAM \\
\hline Flow Velocity & $1984-2018$ & Manacapuru (14100000) & ANA \\
\hline \multirow{2}{*}{ Suspended Sediment } & $1995-2014$ & \multirow{2}{*}{ Manacapuru (14100000) } & HYBAM \\
\cline { 2 - 2 } & $1984-2018$ & & ANA \\
\hline Water Level (Quota) & $1973-2018$ & Manacapuru (14100000) & HYBAM \\
\hline Rainfall & $1984-2018$ & Manaus (82331) & INMET \\
\hline Wild Direction & $1960-1991$ & Manaus (82331) & INMET \\
\hline Seismic Activity & $2014-2018$ & Manacapuru (MACA) & RSBR \\
\hline
\end{tabular}

Org. - The Authors (2020).

Landsat 5 and 8 images with spatial resolution of 30 meters selected at 10-year intervals were used, opting for images with low cloud incidence. The images were preferably selected during the low water period to better obey the changes in the river forms (the only exception was the image of the year 2010 that corresponds to the end of the flood, this occurred due to the lack of better quality images for the area).

Erosion and deposition rates in the study area were calculated using overlapping images and during the period the area was monitored, the short-term evolution of the "Terras Caídas" was observed, using the position of houses, electricity poles as a parameter. and trees, according to the methodology proposed by Carvalho (2011) since, according to the author, the classic methodologies for measuring erosion evolution in river channels are difficult to apply to the "Terras Caídas" process. In order to map areas with predominance of erosion or deposition of the lower Solimões River, the works of Alves (2019) and Franzinelli (2011) were used, in addition to data from this work (2018).

The hydrodynamic factors analyzed were liquid discharge, flow velocity and suspended sediments and the monthly averages were calculated using the historical series data available for the station. According to Filizola and Guyot (2011) the ANA sediment data collection methodology is questioned by several authors, however the data are useful for multitemporal analyzes, so ANA data, in conjunction with HYBAM data, is used to understand the seasonal sedimentological dynamics of the lower Solimões River. For the calculation of suspended sediment load, it was considered that the sediment is transported at the same velocity as the 
flow in every cross section, being equal to the product of the water discharge by concentration (CARVALHO et al., 2000; FILIZOLA; GUYOT, 2011), for this, Equation 1 was used:

$\mathrm{Q}_{\mathrm{ss}}=0,0864 . \mathrm{Q} . \mathrm{C}$

$\mathrm{Q}_{\mathrm{ss}}$ is sediment load in ton/day. $\mathrm{Q}$ is water discharge in $\mathrm{m}^{3} / \mathrm{s}$ and $\mathrm{C}$ is sediment suspension concentration in $\mathrm{mg} / \mathrm{l}$. The constant refers to unit transformation factor.

The water level data were used to understand the ebb velocity of the Solimões River and how it influences the hydrostatic pressure in the lower Solimões River, according to Carvalho (2006; 2012). For the rainfall data, the monthly mean was calculated and for the wind direction data the data from the last climatological normal (1960-1991) were used. The data were used to understand the intensity that extreme events of precipitation and the waves formed by the action of the wind interfere in the "Terras Caídas" events", according to Carvalho (2006; 2012).

Despite the seismic data presenting a four-year historical series, it was decided to include the data in this work to understand the influence of neotectonics in "Terras Caídas" in a shorter time scale. A survey was also carried out in the specific literature of seismic events in the central Amazon region to understand the intensity of the events and how they can interfere in the "Terras Caídas" events. The lithology was analyzed to understand the susceptibility of the soil to erosion in the region.

\section{RESULTS AND DISCUSSION}

\section{EROSION AND DEPOSITION OF SEDIMENTS IN STUDY AREA}

Xiborena Island has convex riverbank, indicating that the depositional process predominated in the area (CHRISTOFOLLETI, 1981; CHARLTON, 2008; STEVAUX; LATRUBESSE, 2017). However, in recent years there has been an increase in area where erosive processes predominate (Figure 2). In Costa do Catalão community, between 2007 and 2009, the soils receded by approximately $200 \mathrm{~m}$, causing loss of plantation, residences, roads, electricity poles and in upstream of community new sedimentary deposits are being used for cultivation and creation of animals by floating community Lago do Catalão. In recent years, erosion in the Costa do Catalão community area has resulted in a migration process that has wiped out the community.

Figure 2 - Erosion and deposition on Xiborena Island.

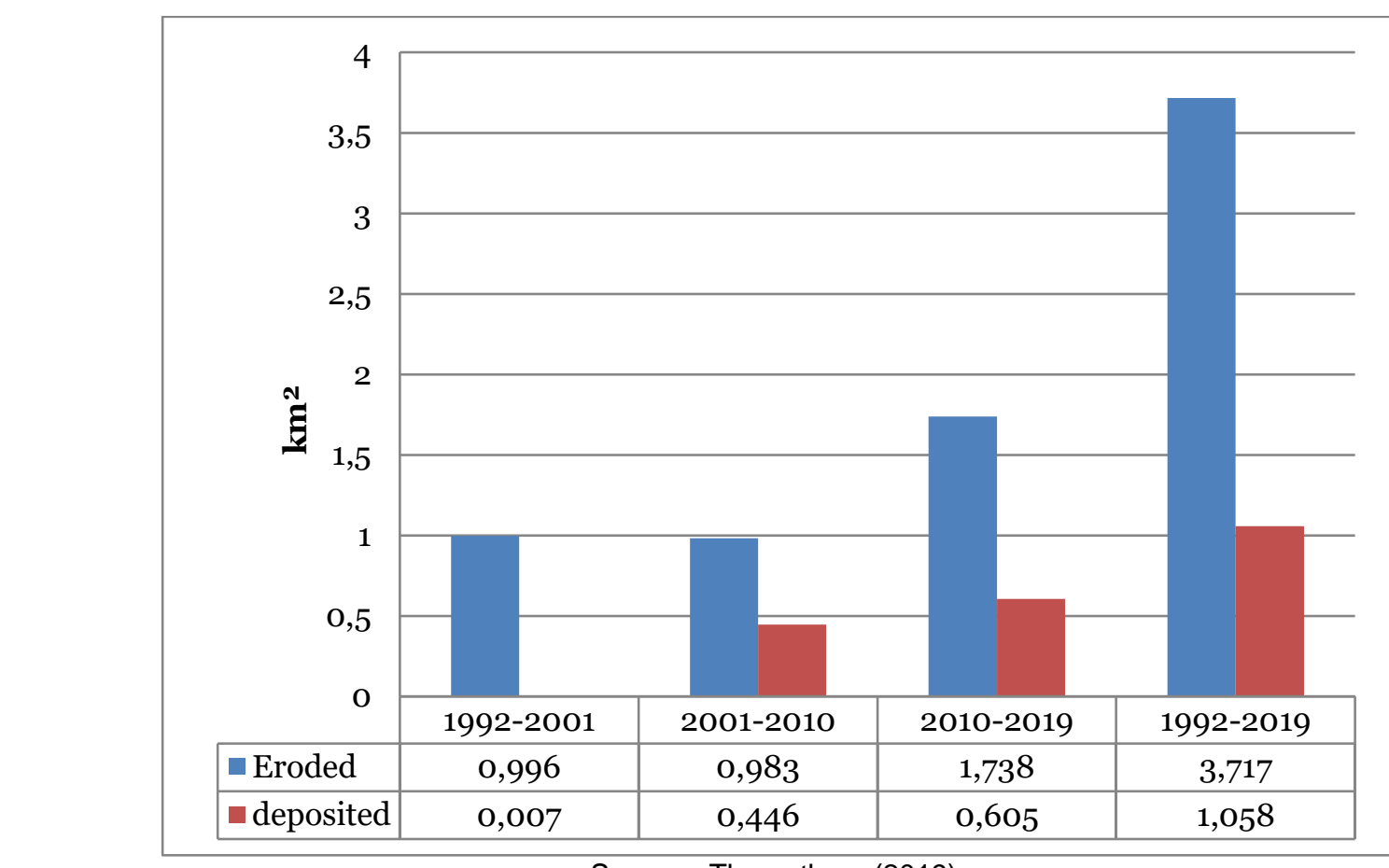

Source - The authors (2019). 
It is observed that comparing the historical series from 1992-2001 and 2001-2010 there was a decrease in erosive processes (-1\%) and an increase in depositional processes (6271\%), with the 1992-2001 historical series showing the lowest rates of deposition. Between the 2001-2010 and 2010-2019 series, erosive processes increased by $71 \%$ and depositional $36 \%$, indicating an increase in erosive processes in 2010-2019 series. However, sedimentary deposits between 2001-2019 are concentrated only at Catalão Tip (Figure 3).

Figure 3 - Areas of erosion and deposition in lower Solimões River.

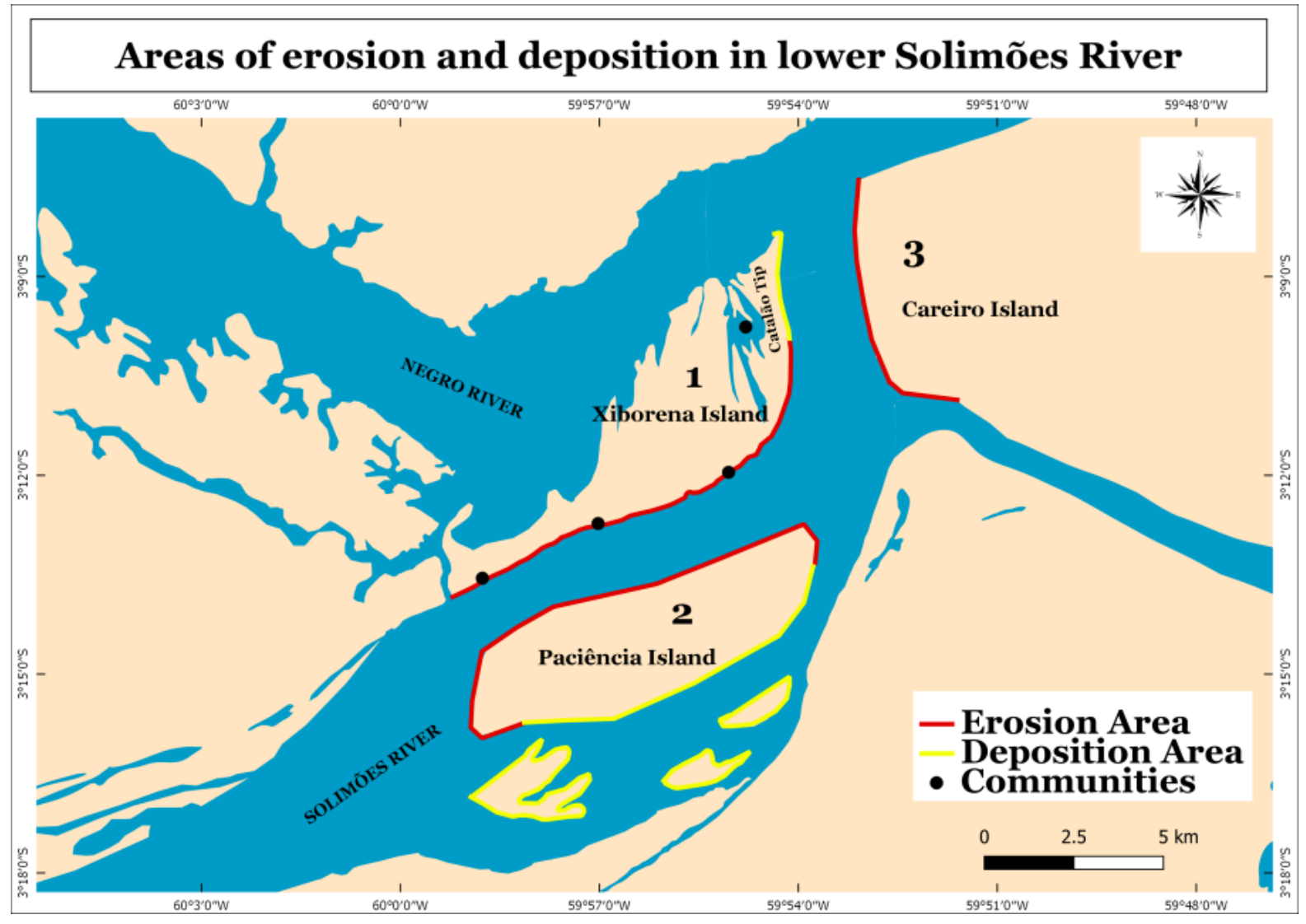

Source - 1: This work (2018). 2: Alves (2019). 3: Franzinelli (2011).

The morphology of the confluence channels has its own characteristics that can interfere in the erosion and sedimentation processes. At the confluence angle, in case of the confluence of the Negro and Solimões Rivers is $90^{\circ}$ (FRANZINELLI, 2011), a zone of flow stagnation forms (BEST, 1987; BIRON; BEST; ROY, 1996; RHOADS; RILEY; MAYER, 2009), becoming a zone conducive to deposition of sediments due to the low flow velocity (HJUSLTROM, 1935). Sedimentation at Catalão Tip and erosion on Careiro Island can modify the morphology of mouth of Solimões River in some years (FRANZINELLI, 2011) and the worsening of deposition process on Paciência Island can increase the hydrodynamic pressure on the left bank of the lower Solimões, increasing the frequency and intensity of "Terras Caídas" process (ALVES, 2019).

\section{HYDRODYNAMICS}

Hydrodynamic is the main conditioning factor of "Terras Caídas", responsible for erosion and transport of sediments from banks of the Amazonian Mega Rivers (CARVALHO, 2006; 2012; IGREJA; CARVALHO; FRANZINELLI, 2010; BANDEIRA et al., 2018). Among the hydrodynamic factors, hydraulic pressure, related to water discharge, is the most important factor to "Terras Caídas" (Figure 4) (CARVALHO, 2012). 
Figure 4 - Water Discharge in Lower Solimões River.

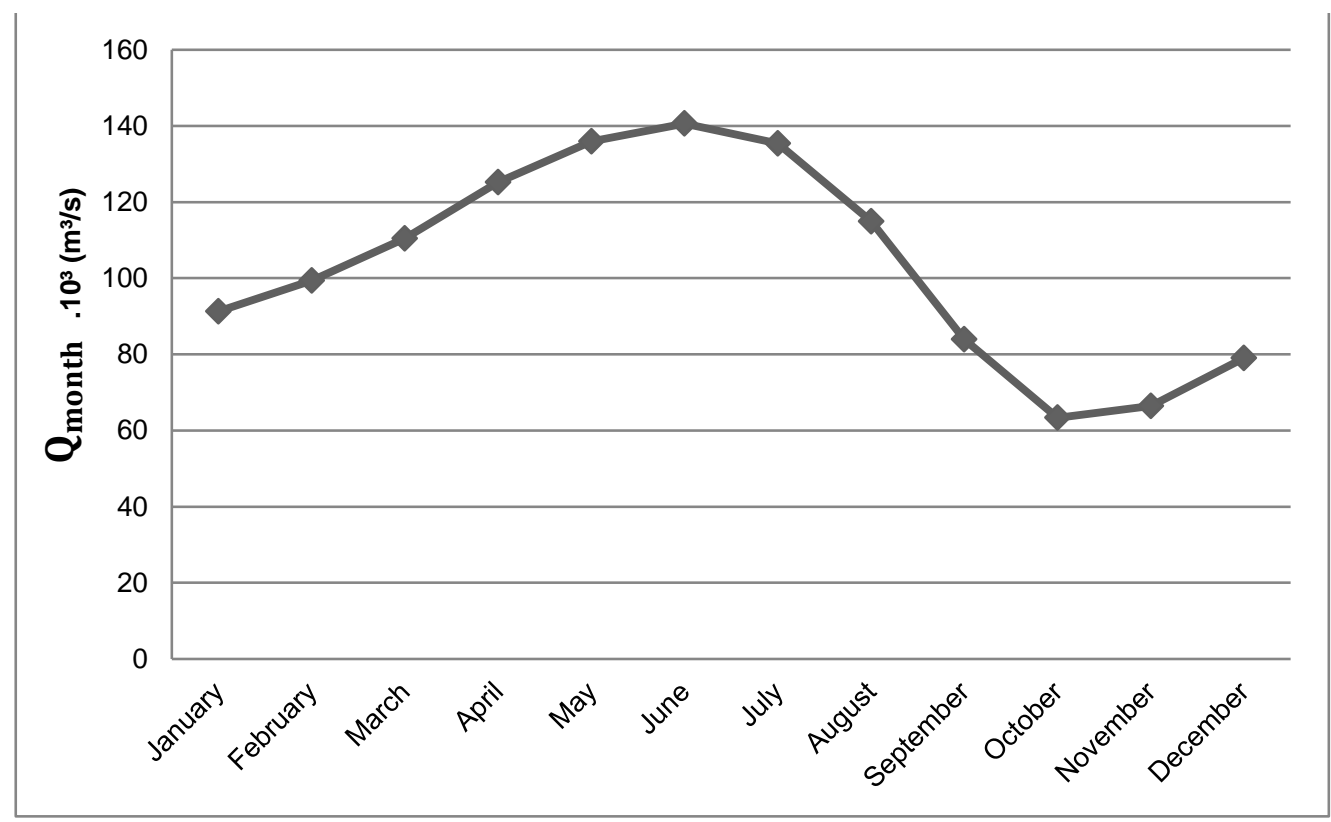

Source - Hybam. Org. - The Authors (2019).

The annual mean discharge to Manacapuru station, the last reference station of the Solimões River, is $103.855 \mathrm{~m}^{3} / \mathrm{s}$. The month with the highest monthly mean discharge is June $\left(140.616 \mathrm{~m}^{3} / \mathrm{s}\right)$, indicating that the peak discharge occurs in this month, and the month with the lowest discharge is October (63.344 $\mathrm{m}^{3} / \mathrm{s}$ ), a variation of $77.272 \mathrm{~m}^{3} / \mathrm{s}$ is observed between the peaks of flood and ebb. At this point Solimões River is the largest river in mean annual discharge in the world (LATRUBESSE; STEVAUX, SINHA, 2005; LATRUBESSE et al., 2005; LATRUBESSE, 2008).

The position of the river thalweg in the cross section influences the stability of the bank and the increase in hydraulic pressure in channel (CUNHA, 1995; NOVO, 2008; MARQUES, 2017). It is observed that in the study area the river thalweg is close to the left bank, even though there is variation in its location, depending on the reference year (Figure 5) (FRANZINELLI, 2011). Currently in the study area the thalweg is approximately $65 \mathrm{~m}$ from the left bank (ALVES, 2019).

Figure 5 - Cross-sectional profile of the Solimões and Negro Rivers.

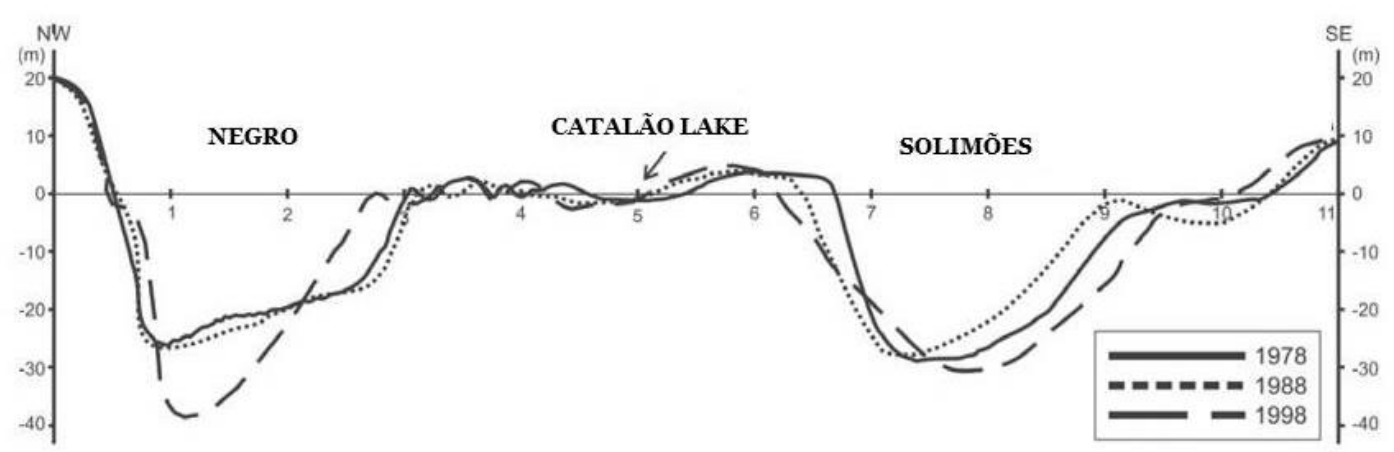

Source - Adapted from Franzinelli (2011).

Turbulence and flow velocity are closely linked to the river's work (CHRISTOFOLETTI, 1981). The "Terras Caídas" are associated with macro turbulence due to the large volume of water transported by river, the flow moves upward, vortexes and helical, with upward swirling flow the main cause of the "Terras Caídas" (STERNBERG, 1998; CARVALHO, 2012). The flow velocity (Hydraulic Power) (Figure

$\begin{array}{llllll}\text { Caminhos de Geografia } \quad \text { Uberlândia-MG } & \text { v. 22, n. } 80 & \text { abr./2021 } & \text { p. 220-233 Página } 225\end{array}$


6) is important in removing particles from the riverbanks, the higher the velocity the greater the diameter of the eroded material (HJUSLTROM, 1935; 1939).

Figure 6 - Flow Velocity in Lower Solimões River.

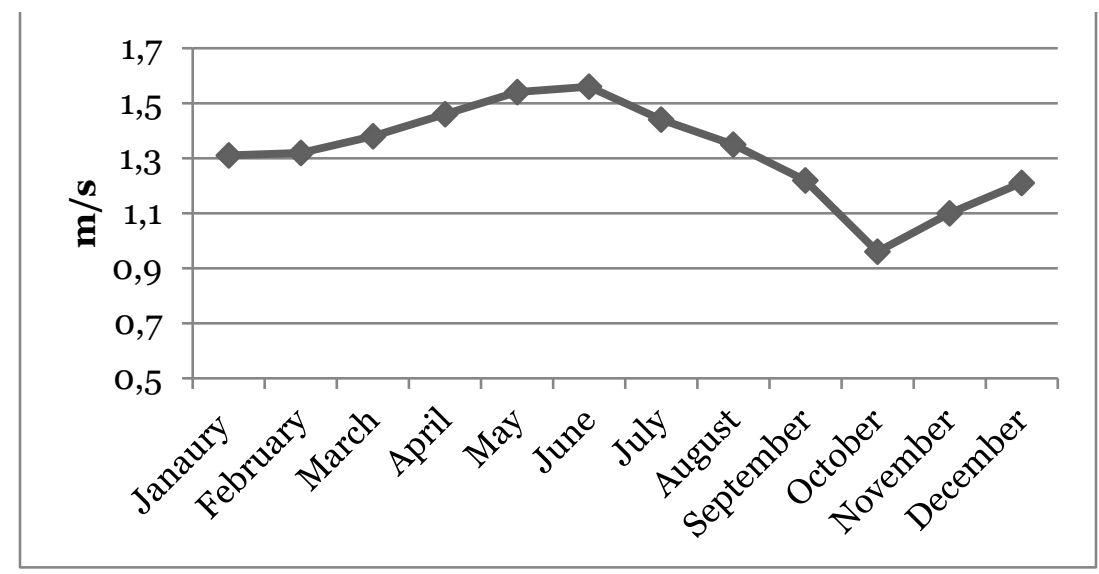

Source - ANA. Org. - The authors, 2019.

The month with the highest monthly mean of flow velocity is June $(1,56 \mathrm{~m} / \mathrm{s})$ and the month with the lowest monthly mean is October $(0,97 \mathrm{~m} / \mathrm{s})$, it is noted that the highest and lowest value correspond to discharge peaks in flood and ebb, respectively. However, the absolute velocity values vary from $2,5 \mathrm{~m} / \mathrm{s}$ and $3 \mathrm{~m} / \mathrm{s}$, concentrating on the left bank (NASCIMENTO, 2016). The flow velocity in the study area has the power to erode silt, clay and sand (HJUSLTROM, 1935).

In left bank of lower Solimões River, the soil with silty texture predominates (MAGALHÃES, 2011), although silt is a material more resistant to erosion (MORISAWA, 1968), in "Terras Caídas" the predominance of silt decreases the stability of the bank, making it more conducive to erosive processes (FREITAS; ALBUQUERQUE, 2012).

Suspended sediments, in the case of hyperconcentrated flows, are an important factor for erosion in rivers (JIONGXIN, 1999). Analyzing the "Terras Caídas" Igreja, Carvalho and Franzinelli (2010) observed the importance of suspended load as a conditioning factor; however, few studies have investigated the real influence of suspended sediments on "Terras Caídas" events. At Manacapuru station the interannual sediment load is $383.10^{6}$ ton/year, according to the HYBAM database (FILIZOLA; GUYOT, 2011), and $~ 400.10^{6}$ ton/year, for the ANA database (FILIZOLA; GUYOT, 2009). It's observed the values of Suspended Sediments (Qss) distributed monthly in Figure 7:

Figure 7 - Suspended Sediment in Lower Solimões River

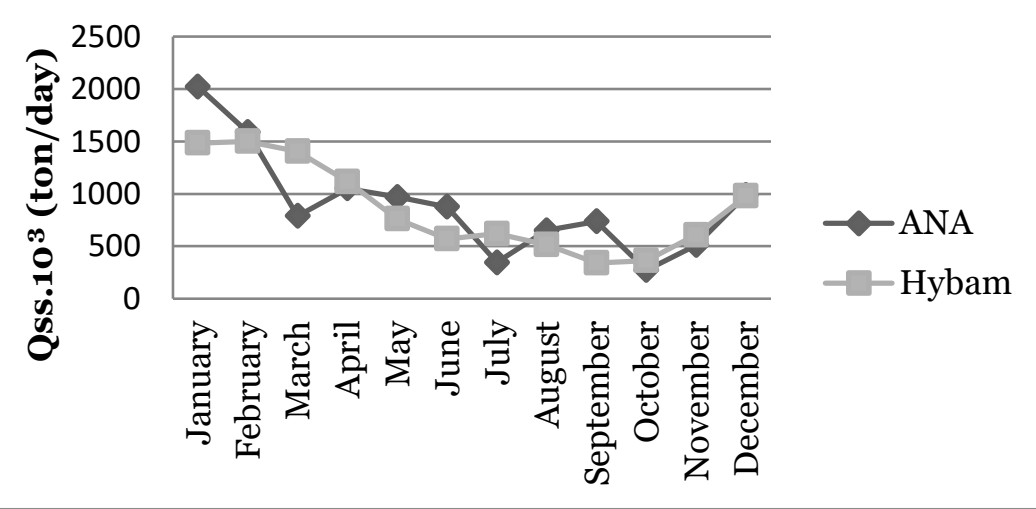

Source - Hybam and ANA. Org. - The Authors (2019).

The sediments that the river carries in suspension reaches its peak between January, February and March, it is noted that the peak of suspended sediments at Manacapuru station occurs before the peak 
of water discharge, as observed by Filizola and Guyot (2011). In Hybam data the lowest value was found in September (340.493 ton/day), while the highest was in February (1.499.732 ton/day). ANA data indicate the lowest value in October (272.401 ton/day) and the highest in January (2.022.790 ton/day). It's concluded that erosion influences the suspended sediments is more efficient during the flood period of the Solimões River and works in conjunction with hydraulic pressure and hydraulic power, causing basal erosion and disaggregating large volumes of sediments (sand, silt, clay) and vegetation into the flow (Figure $8 \mathrm{a}, \mathrm{b}, \mathrm{c}$ ).

Figure 8 a, b, c - "Terras Caídas" caused by hydrodynamics factors.

A)

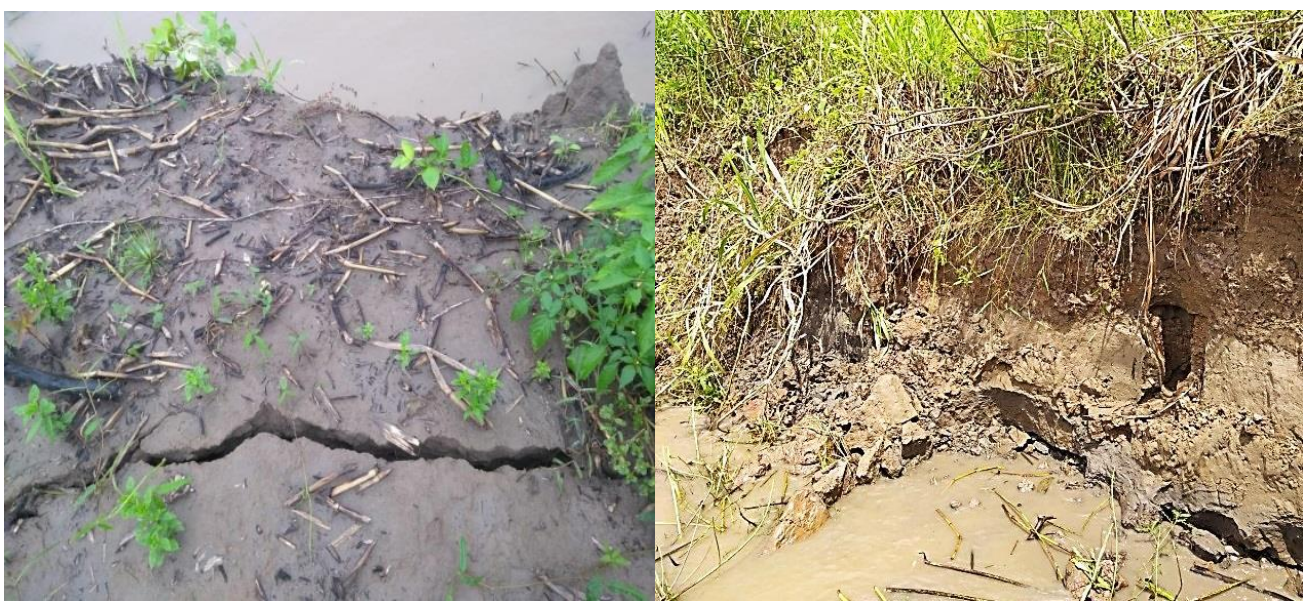

C)

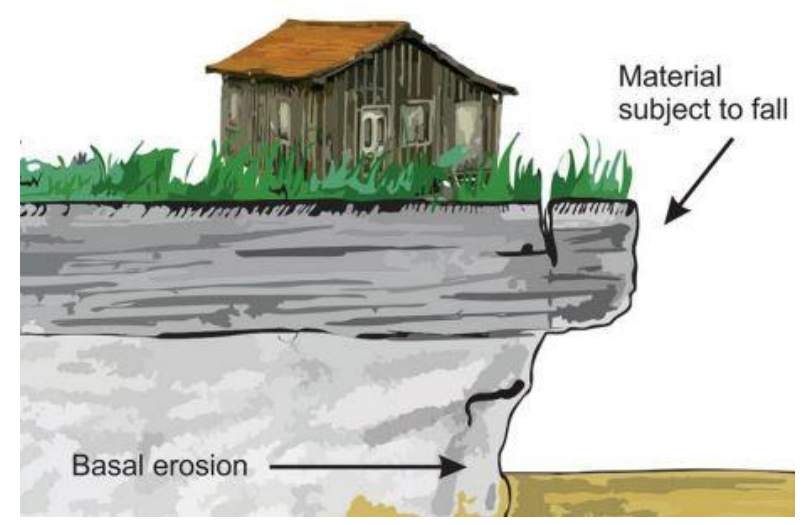

Figure 8a - Orthogonal fracture in riverbank caused by basal erosion, February 2018, water level: $1482 \mathrm{~cm}$, in

Costa do Catalão community. Figure 8b - Basal erosion and semicircular structure formed in the ebb flow,

February 2018, water level: $1476 \mathrm{~cm}$, in Santa Luzia community. Source - The authors (2018). Figure 8c -

Schematic displaying the undermining process during dry flow and part of flood flow. Source - Bandeira et al. (2018).

\section{Hydrostatic Pressure}

Hydrostatics is the term that is commonly used in the technical literature to describe the behavior of fluids, particularly fluids at rest. Unlike fluid in motion, a fluid at rest in relation to its limits tends to be in a state of shear stress is zero, thus the pressure imposed on point of fluid mass at rest is transmitted in all directions without reduction (KINDSVATER, 1958). On riverbanks, this process occurs due to the rapid lowering of the water level; therefore, drop in the level of the piezometric surface will not follow of river level (quota). (GUIDICINI; NIEBLE, 1983; TERZAGHI, 1950).

Hydrostatic pressure is an important conditioning factor for "Terras Caídas" in the Amazon (TRICART, 1977). The ribeirinhos (Riverside People) classify, in a generic way, the resulting process as land

$\begin{array}{lllll}\text { Caminhos de Geografia } \quad \text { Uberlândia-MG } & \text { v. 22, n. } 80 \quad \text { abr./2021 } & \text { p. 220-233 Página } 227\end{array}$


collapse (CARVALHO, 2012; BANDEIRA et al., 2018). The water that covers the floodplain during the flood, leaving it completely covered for approximately three months (May, June, July), allowing water to infiltrate the soil. The pressure exerted by the water in the soil occurs during the ebb, causing sliding on riverbank (Figure 9 a, b) (ALVES, 2013; STERNBERG, 1998). During the ebb, semicircular structures are formed at the riverbank, influenced by hydrostatic pressure, which during the flood are saturated with water (see figure 8) (TRICART, 1977).

Figure 9 a, b - "Terras Caídas" caused by hydrostatic pressure.

A)

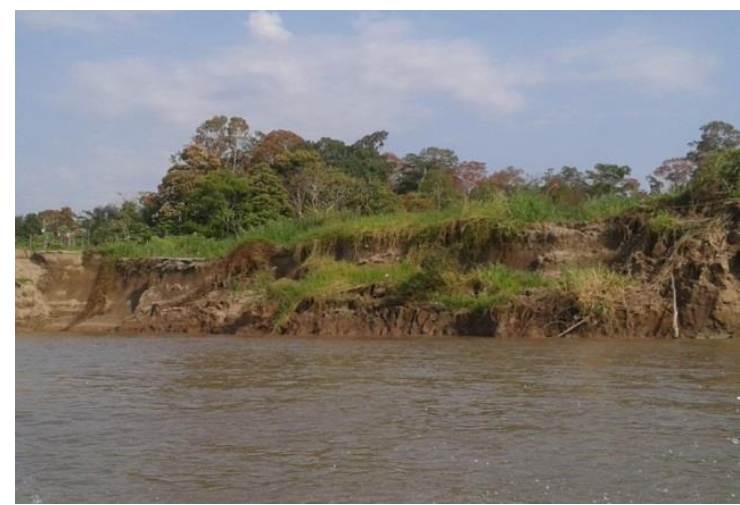

B)

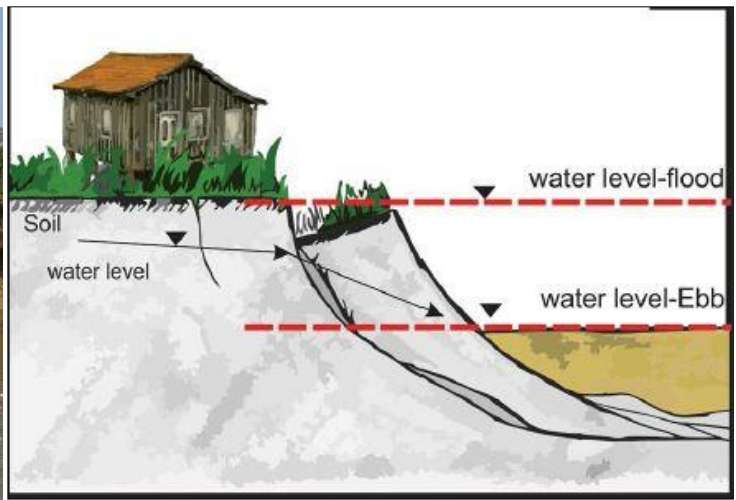

Figures 9a: Riverbank Slide, August 2017, water level: $1723 \mathrm{~cm}$, Bom Jesus do Paraná do Xiborena community. Source: The authors (2017). Figure 9b: Illustrative profile exhibiting the basic geomechanical model of sliding hazards in riverbanks. Source - Bandeira et al. (2018).

The Manacapuru Station indicates that between the months of January and April the river level rises, reaching the peak of flooding in June. The level of the river begins to descend from the second half of July, beginning to ebb (Figure 10). The piezometric level in lower Solimões River begins to rise in May and to descend in July/August, but in a delayed manner at level of Solimões River (MAGALHÃES, 2011; MAGALHÃES; VIEIRA, 2018).

Figure 10 - Water Level (Quota) in Lower Solimões River.

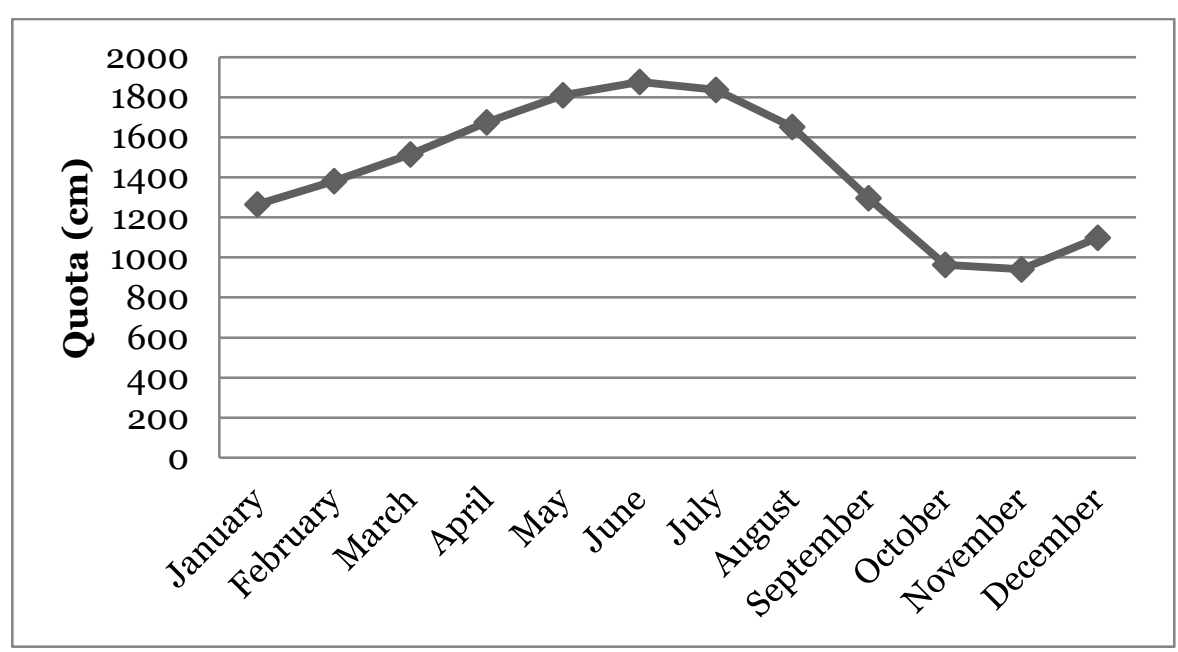

Source - Hybam. Org. - The Authors (2019).

In 2017, in the second half of July, the river level dropped $84 \mathrm{~cm}$, in August $440 \mathrm{~cm}$ and in September $547 \mathrm{~cm}, 322 \mathrm{~cm}$ only in the first half of month. In 2018, in second half of July, the river level dropped 57 $\mathrm{cm}$, in August $212 \mathrm{~cm}$ and in September $353 \mathrm{~cm}$. It is observed that in the year 2017 the Solimões River level dropped faster, indicating greater influence of hydrostatic pressure in the study area, during the monitoring period, this year.

$\begin{array}{lllll}\text { Caminhos de Geografia } \quad \text { Uberlândia-MG } & \text { v. 22, n. } 80 & \text { abr./2021 } & \text { p. 220-233 Página } 228\end{array}$




\section{RAINFALL AND WIND}

The mean annual rainfall at the Manaus station is $2245.4 \mathrm{~mm} / \mathrm{year}$. The months with the highest rainfall are January, February, March, April and May (Figure 11), with the rainy season occurring between December and May. When there are large volumes of precipitation in a short time, the soil saturated due to porosity and permeability, making terraces and floodplains heavy, conditioning the mass movement. According to Carvalho (2006; 2016), "Terras Caídas" events occur more frequently when there is an increase in precipitation and hydrodynamic pressure.

Figure 11 - Rainfall at Manaus Station.

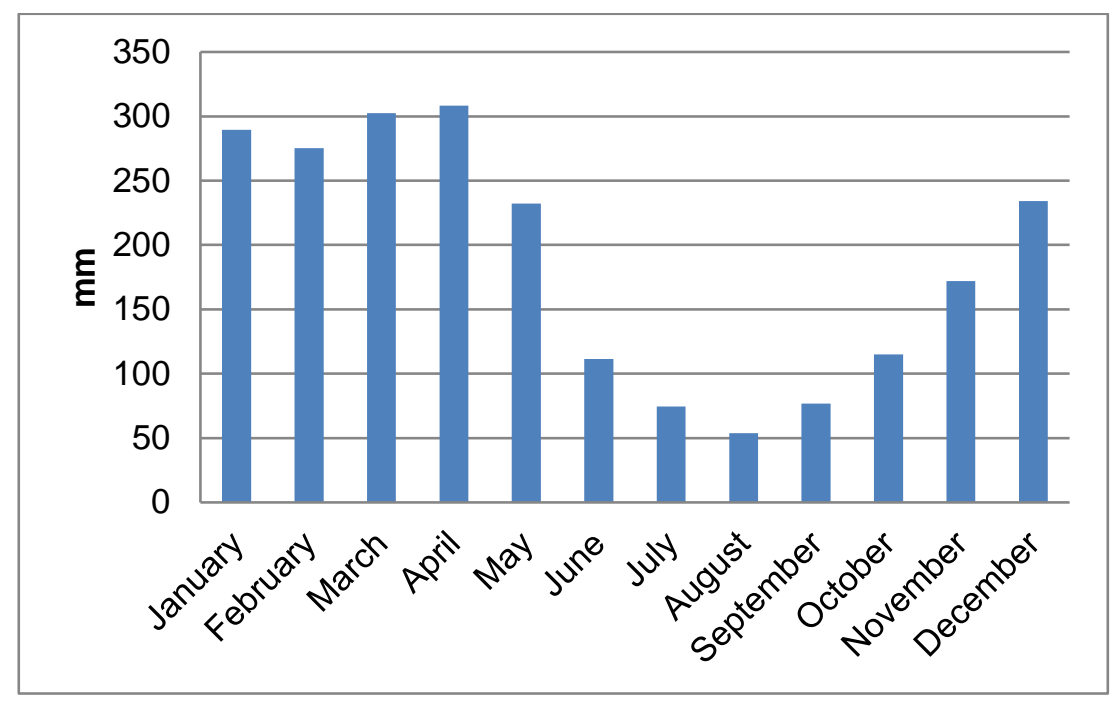

Source - INMET. Org. - The Authors (2019).

In large rivers, the abrasive action of waves driven by winds can cause undermining of banks (MEIS, 1968; THORNE, 1991; KOTOKY, 2005; CARVALHO, 2006; 2012), and in wide channels, as is the case of lower Solimões River, the wind speed increases, intensifying the waves, however there are still no detailed studies on the frequency and magnitude of the waves and their influence on erosion processes (BANDEIRA et al., 2018). The wind direction in study area is predominantly NE, except for August and September (SE) (Table 2), indicating that the waves formed by the winds may affect the study area on a smaller scale. During storms, this process occurs with greater intensity.

Table 2 - monthly mean wind direction.

\begin{tabular}{|c|c|}
\hline Month & Wind Direction \\
\hline January & NE \\
\hline February & NE \\
\hline March & NE \\
\hline April & NE \\
\hline May & NE \\
\hline June & NE \\
\hline July & NE \\
\hline August & SE \\
\hline September & SE \\
\hline October & NE \\
\hline November & NE \\
\hline December & NE \\
\hline
\end{tabular}

Source - INMET. Org. - The Authors (2019). 


\section{LITHOLOGY AND NEOTECTONICS}

The lithology of the lower Solimões floodplain is composed of holocenic alluvial deposits (LATRUBESSE; FRANZINELLI, 2002), and fluvic neossol predominating in the area of left bank of lower Solimões River (MAGALHÃES; GOMES, 2013), indicating soil with low stability and susceptible to erosive processes and mass movement.

Neotectonics "has been responsible for the events of larger "Terras Caídas", especially along the rivers..." (IGREJA; CARVALHO; FRANZINELLI, 2010, p. 139). The confluence of the Negro and Solimões rivers is located in the transcurrent neotectonic strip that covers the entire Central Amazon (IGREJA, 1998), occurring intersections of the N40E and N65W structural directions and interfering in the holocenic syntectonic deposits on Xiborena Island (FRANZINELLI, 2011). The reactivation of syntectonic deposits can condition events of "Terras Caídas" (IGREJA, CARVALHO; FRANZINELLI, 2010).

Manaus is considered a seismogenic zone with epicenters located around the confluence between the Negro and Solimões rivers (COSTA et al., 1996; MIOTO, 1993). Downstream of the study area, an earthquake with an estimated magnitude of $\sim 7$ was recorded in 1690, being considered the largest in the Amazon region, afterwards earthquakes were recorded in the region of the municipality of Codajás in 1963, upstream of the study area, with magnitude of 5.1, result of a reverse fault oriented NNE; and in the municipality of Manaus in 1980, with magnitude 3.4, the result of a reverse fault oriented approximately to NNW, probably the tremors of these events affected the study area (ASSUMPÇÃO; SUÁREZ, 1988; VELOSO, 2014). However, at Manacapuru station (MACA) in 2014-2020 historical series there are no seismic records, indicating that, in recent years, when the events of "Terras Caídas" have intensified, this has not been a conditioning factor for Xiborena Island.

\section{ANTHROPIC INTERFERENCE}

The human interference is a determinant of "Terras Caídas", occurring to a lesser extent (BANDEIRA et al.; CARVALHO, 2012). In study area there are three rural communities (Costa do Catalão, Santa Luzia and Bom Jesus do Paraná do Xiborena), which promoted the removal of riparian forest for planting short-cycle agricultural crops and pastures for animals. Sternberg (1998) considers that removal of vegetation has little effect on increasing the intensity of the process, however the presence of vegetation influences the infiltration speed and the variation of the piezometric level, so that erosion occurs slowly (mainly the hydrostatic pressure) (COSTA et al., 1996; SUTILI, 2007; BANDEIRA et al., 2018).

Boat action that promotes waves that contribute to basal erosion, which may cause "Terras Caídas", with the speed of the boats being the main factor in the formation of waves and the intensity of the impact with the riverbanks (CARVALHO, 2006; 2012; QUEIROZ; SOARES; TOMAZ NETO, 2018; BANDEIRA et al., 2018). Currently, river locomotion is the main means of transport in the Amazon, with boats that can reach speeds above $50 \mathrm{~km} / \mathrm{h}$.

\section{FINAL CONSIDERATIONS}

In last ten years (2010-2019) the area of eroded sediments has increased by $71 \%$ and although the area of deposited sediments has increased this has only occurred in Catalão Tip. The factors that influenced "Terras Caídas" in lower Solimões River are mainly hydrodynamics, hydrostatic pressure, rainfall and wind; lithology, neotectonics and anthropic influence occur on a smaller scale.

The hydrodynamic factors and the rain influence the "Terras Caídas" more intensely during the river flood, the processes influenced by the wind direction occur throughout the hydrological year, but with greater intensity during storms. Hydrostatic pressure occurs more frequently in the ebb causing landslides. The lithology influences the stability of the riverbanks due to unconsolidated sediments, providing erosion and mass movements. It is observed that, despite being present in the region, neotectonics was not important in increasing the intensity of the "Terras Caídas" in the study area in 
recent years. Human activity influences destroying riparian forests and the basal erosion caused by waves formed by boats in the region.

\section{REFERENCES}

ALVES, A.C. Análise Multitemporal e Morfodinâmica no Entorno da Confluência do Rio Solimões com o Rio Negro. Dissertação (Programa de Pós-Graduação em Geografia, Universidade Federal do Amazonas - UFAM), Manaus, 2019.

ALVES, N.S. Mapeamento Hidromorfodinâmico do Complexo Fluvial de Anavilhanas: Contribuição aos estudos de Geomorfologia Fluvial de Rios Amazônicos. 2013. Tese (Doutorado em Geografia Física) - Faculdade de Filosofia, Letras e Ciências Humanas, Universidade de São Paulo, São Paulo, 2013. 232p.

ASSUMPÇÃO, M., SUÁREZ, G. Source mechanisms of moderate-size earthquakes and stress orientation in mid-plate South America. Geophysical Journal, v. 92, p. 253-267, 1988. https://doi.org/10.1111/j.1365-246X.1988.tb01138.x

BANDEIRA, I.C.N.; ADAMY, A.; ANDRETTA, E.R.; CONCEIÇÃO, R.A.C.; ANDRADE, M.M.N. Terras caídas: Fluvial erosion or distinct phenomenon in the Amazon?. Environmental Earth Sciences, v. 77, n. 222, 2018. https://doi.org/10.1007/s12665-018-7405-7

BEST, J.L. Flow dynamics at river channel confluence: Implications for sediment transport and bed morphology. In: ETHERIDGE, F.G.; FLORES, R.M; HARVE, M.D. (Orgs.). Recent Developments in Fluvial Sedimentology. Society of economic Paleontologists and mineralogists, Special Publication, SEPM: Tulsa, n. 39, p. 27-35, 1987. https://doi.org/10.2110/pec.87.39.0027

BIRON, P.; BEST, J.L.; ROY, A.G. Effects of bed discordance on flow dynamics at open channel confluences. Journal of Hydraulic Engineering, n. 122, p. 676-682, 1996. https://doi.org/10.1061/(ASCE)0733-9429(1996)122:12(676)

CARVALHO, J. A. L. Erosão Nas Margens do Rio Amazonas: o Fenômeno das Terras Caídas e suas Implicações na vida dos moradores. Tese - Programa de Pós-Graduação em Geografia. Niterói/RJ: Universidade Federal Fluminense, 2012.

CARVALHO, J. A. L. Terras caídas e consequências sociais: Costa do Miracauera, Paraná da Trindade, Município de Itacoatiara-AM. Dissertação (Mestrado no Programa de Pós-Graduação Sociedade e Cultura na Amazônia do Instituto de Ciências Humanas e Letras) - Universidade Federal do Amazonas. Manaus, 2006, 142p.

CARVALHO, N.O.; FILIZONA, N.P.; SANTOS, P.M.C.; LIMA, J.E.F.W. Guia de Práticas Sedimentométricas. Agência Nacional de Energia Elétrica: Superintendência de Estudos e Informações Hidrológicas, Brasília, 2000.

CHARLTON, R. Fundamentals of Fluvial Geomorphology. Routledge: London and Ney York, 2008. https://doi.org/10.4324/9780203371084

CHRISTOFOLETTI, A. Geomorfologia Fluvial. São Paulo: Edgard Blucher, 1981, vol. 1. 313 p.

COSTA, J. B. S.; BEMERGUY, R. L.; HASUI, Y. ; BORGES, M. S ; FERREIRA JÚNIOR, C. R. P. ; BEZERRA, P. E. L.; COSTA, M. L.; FERNANDES, J. M. G. Neotectônica Da Região Amazônica: Aspectos Tectônicos, Geomorfológicos e Deposicionais. Geonomos, Belo Horizonte, v. 4, n. 2, p. 2344, 1996. https://doi.org/10.18285/geonomos.v4i2.199

CUNHA, S. B. Impactos das obras de engenharia sobre o ambiente biofísico da bacia do rio São João. Rio de Janeiro: Edição do Autor, 1995.

FILIZOLA, N.; GUYOT, J.L. Fluxo de sedimentos em suspensão nos rios da Amazônia. Revista Brasileira de Geociências, v. 41, n. 4, p 566-576, 2011. https://doi.org/10.25249/0375$\underline{7536.2011414566576}$

FILIZOLA, N.; GUYOT, J.L. Suspended Sediment Yield in the Amazon Basin: an Assessment Using Brazilian National Data Set. Hydrological Processes, v. 23, n. 22, p. 3207- 3215, 2009. https://doi.org/10.1002/hyp.7394 
FRANZINELLI, E. Características morfológicas da confluência dos rios Negro e Solimões (Amazonas, Brasil). Revista Brasileira de Geociências, v. 41, n. 4, p 587-596, 2011. https://doi.org/10.25249/0375$\underline{7536.2011414587596}$

FREITAS, F.T.; ALBUQUERQUE, A.R. Análise Temporal Sobre as "Terras Caídas" no Médio Solimões/Coari (AM). Mercator, Fortaleza, v. 11, n. 25, p. 129-140, 2012. https://doi.org/10.4215/RM2012.1125.0010

GUERRA, A. T.; GUERRA, A. J. T. Novo dicionário geológico-geomorfológico. BERTRAND BRASIL, Rio de Janeiro, $11^{\circ}$ ed., 2015.

GUIDICINI, G.; NIEBLE, C.M. Estabilidade de Taludes Naturais e de Escavação. Blunch: São Paulo, 1983.

HJULSTROM, F. Transportation of debris by moving water. In: TRASK, PD (Org.). Recent marine sediments; a symposium. American Association of Petroleum Geologists, Tulsa, p. 5-31, 1939. https://doi.org/10.2110/pec.55.04.0005

HJUSLTROM, F. Studies of morphological activity of rivers as illustrated by the River Fyris. University of Upsala Geological Institute Bulletin, n. 25, p. 221-527, 1935.

IGREJA, H. Aspectos do Modelo Neotectônico da Placa Sul-Americana na Província Estrutural Amazônica, Brasil. Tese (Acesso à classe de professor titular) - Universidade Federal do Amazonas - UFAM, Manaus, 1988.

IGREJA, H.LS; CARVALHO, J.A.L.; FRANZINELLI, E. Aspectos das Terras Caídas na Região Amazônica. In: ALBUQUERQUE, A.R. (Org.). Contribuições Teórico-Metodológica da Geografia Física. EDUA: Manaus, p. 135-153, 2010.

JIONGXIN, X. Erosion caused by hyperconcentrated flow on the Loess Plateau of China. Catena, $\mathrm{n}$. 36, p. 1-19, 1999. https://doi.org/10.1016/S0341-8162(99)00009-0

KINDSVATER, C.E. Selected Topics of Fluid Mechanics. In: KINDSVATER, C.E. (Org.). River Hydraulics. UNITED STATES GOVERNMENT PRINTING OFFICE, WASHINGTON, p. 1-51, 1958.

KOTOKY, P. et al. Nature of erosion along the Brahmaputra river channel, Assam, Índia. Current Science, Vol. 88, № 4, 25 February, 2005. p. 634-640.

LATRUBESSE, E. M. Patterns of anabranching channels: The ultimate end-member adjustment of $\begin{array}{lllll}\text { mega } & \text { rivers. } & \text { Geomorphology } & 101, & 130-145,\end{array}$ https://doi.org/10.1016/j.geomorph.2008.05.035

LATRUBESSE, E.M.; FRANZINELLI, E. The Holocene alluvial plain of the middle Amazon River, Brazil. Geomorphology, v. 44, p. 241 - 257, 2002. https://doi.org/10.1016/S0169-555X(01)00177-5

LATRUBESSE, E.M.; STEVAUX, J.C.; SANTOS, M.L.; ASSINE, M.L. Grandes Sistemas Fluviais: Geologia, geomorfologia, paleohidrologia. In: SOUZA, C.R.G.; SUGUIU, K.; OLIVEIRA, A.M.S.; OLIVEIRA, P.E. (Orgs.). Quaternário Brasileiro. Ribeirão Preto: Holus Editora, p. 276-297, 2005. https://doi.org/10.1016/i.geomorph.2005.02.005

LATRUBESSE, E.M.; STEVAUX, J.C.; SINHA, R. Tropical rivers. Geomorphology, v.70 , p. 187-206, 2005.

MAGALHÃES, R.C. As Características Físicas, Químicas, Mineralógicas e Hidráulicas do Solo e sua Susceptibilidade ao Processo de Terras Caídas: Comunidade do Divino Espírito Santo Iranduba/AM. Dissertação (Programa de Pós-Graduação em Geografia da Universidade Federal do Amazonas), Manaus, 2011.

MAGALHÃES, R.C.; GOMES, R.C.M. Mineralogia e química de solo de várzea e suas susceptibilidades no processo de terras caídas na comunidade do Divino Espírito Santo-AM. Sociedade e Natureza, v. 25, n. 3, Uberlândia, 2013. https://doi.org/10.1590/S1982-45132013000300013

MAGALHÃES, R.C.; VIEIRA, A.F.S.G. As Características Hidrológicas do solo de Várzea e sua Vulnerabilidade ao Processo de Terras Caídas na Amazônia Central (BR). Revista Brasileira de Geografia Física, v.11, n.03, p. 773-788, 2018. https://doi.org/10.26848/rbgf.v10.6.p773-788 
MARQUES, R.O. Erosão nas Margens do Rio Amazonas: O Fenômeno das Terras Caídas e as Implicações para a Cidade de Parintins-AM. Dissertação (Programa de Pós-Graduação em Geografia, Universidade Federal do Amazonas - UFAM), Manaus, 2017.

MEIS, M. R. M de. Considerações geomorfológicas sobre o Médio Amazonas. Revista Brasileira de Geografia-IBGE. Rio de Janeiro, 2: 3-20,1968.

MIOTO, J.A. Sismicidade e zonas sismogênicas do Brasil. Tese (Universidade Estadual Paulista Júlio de Mesquita Filho - UNESP). Rio Claro, 1993.

MOLINIER, M.; GUYOT. J.L.; OLIVEIRA, E.; GUIMARÃES, V. Les Régimes Hydrologiques de L'amazone et de ses Affluents. In: CHEVALLIER, P.; POUYAUD, B. (org.) L'hydrologie Tropicale: Géoscience et Outil Pour le Développement. Paris, IAHS, pp. 209-222, 1996.

MORISAWA, M.E. Strems: Their dynamics and morphology. McGraw-Hill Book, New York, 1968.

NASCIMENTO, A.Z.A. Características Hidro-Geomorfológicas do Baixo Curso dos Rios Solimões e Negro, e sua Confluência, Amazônia, Brasil. Dissertação (Programa de Pós-Graduação em Geografia: Amazônia - Território e Ambiente), Manaus, 2016.

NOVO, E. M. L. M. Ambientes Fluviais. In: FLORENZANO, Teresa G. (Org.). Geomorfologia, conceitos e tecnologias atuais. São Paulo: Oficina de Textos, 2008.

QUEIROZ, M.S; SOARES, A.P.A; TOMAZ NETO, A.G. Comunidades rurais ribeirinhas e as águas do rio Solimões no município de Iranduba - Amazonas. Revista Brasileira de Meio Ambiente, v.4, n.1.108-119, 2018.

RHOADS, B.L; RILEY, J.D; MAYER, D.R. Response of bed morphology and bed material texture to hydrological conditions at an asymmetrical stream confluence. Geomorphology, n. 109, p. 161-173, 2009. https://doi.org/10.1016/j.geomorph.2009.02.029

SIOLI, H. A limnologia e a sua importância em pesquisas da Amazônia. Amazoniana, p. 11- 35, 1965. STERNBERG, H. O'R. A água e o homem na várzea do Careiro. Belém: Museu Paraense Emílio Goeldi, 1998.

STEVAUX, J. C.; LATRUBESSE, M. E. Geomorfologia Fluvial. Oficina de Textos: São Paulo: 2017.

SUTILI, F.J. Bioengenharia de solos no âmbito fluvial do sul do Brasil. Tese (doutorado em Engenharia Natural, Universidade Rural de Viena), Viena, 2007. 95p.

TERZAGHI, K. Mechanism of Landslides. Application of Geology to Engineering Practice, Sidney Paige, 1950.

THORNE, C. R. Bank erosion and meander migration of the Red and Mississippi Rivers, USA. In: Hydrology for the Water Management of large River Basins (Proceedings of the Vienna Symposium, August, 1991). IAHS public.№ 201, 1991.

TRICART, J. Tipos de planícies aluviais e de leitos fluviais da Amazônia brasileira. Revista Brasileira de Geografia - IBGE. Rio de Janeiro, 1977. 3-37 p.

VELOSO, A. On the footprints of a major Brazilian Amazon earthquake. An. Acad. Bras. Ciências,vol.86, no.3, Rio de Janeiro, 2014. https://doi.org/10.1590/0001-3765201420130340 